\title{
What Makes a Young Entrepreneur?
}

\section{David G. Blanchflower}

Bruce V. Rauner Professor of Economics Dartmouth College, University of Stirling, NBER, IZA and Member of the Monetary Policy Committee Bank of England

Email: blanchflower@dartmouth.edu and david.blanchflower@,bankofengland.co.uk

Webpage: www.dartmouth.edu/ blnchflr

\section{Andrew J. Oswald}

Department of Economics University of Warwick, UK

Email: andrew.oswald@warwick.ac.uk

Webpage: http://www.andrewoswald.com/

Wednesday, October $24^{\text {th }}, 2007$ 
A rule of thumb is that youth unemployment rates tend to be approximately twice the adult rate. The most recent 2006 figures, for example, from the 2007 OECD Employment Outlook, reveal a EU15 unemployment rate in 2006 of $16.1 \%$ among those 15-24 years of age, compared to a rate of 7.0\% among those $25-54$ and $6.4 \%$ for $55-64$ year olds. The figures for the OECD as a whole were $12.5 \% ; 5.4 \%$ and $4.4 \%$ respectively. Unemployment rates for 18-24 year olds in 2006 were especially high in Belgium (18.9\%); Finland (18.8\%); France (23.9\%); Greece (24.5\%); Italy (21.6\%); Poland (29.8\%); Slovak Republic (26.6\%) and Sweden (21.3\%). In the UK, for example, the proportion of total unemployment accounted for by those aged 18-24 has increased steadily over the past decade: in 1997 it was $23.9 \%$ of the unemployed compared with $30.8 \%$ in the latest available data at the time of writing for June-August 2007 (Source: Labour Market Statistics, First Release, October 2007, ONS, Table 9(1). Therefore in countries with the most severe youth unemployment rates, such as France, a quarter of young people can be looking for work. It is widely accepted that this is not merely a short-run waste of human resources and a source of unhappiness among Europe's young people. It may have long-term scarring effects on the working adults of the next generation. For many years, Europe has had a large group of young people outside education and the workplace. The persistence of the problem seems to demonstrate that standard economic policies have been insufficient. Western governments are searching for new alternatives. One is the idea that policy should attempt to create more entrepreneurship among the young.

It is not obvious that even a large new supply of young entrepreneurs would solve the jobs crisis. Nevertheless, there are a number of 'potential' benefits often discussed by commentators.

- Entrepreneurship may promote innovation and thus create new jobs.

- There may be a direct effect on employment if new young entrepreneurs hire fellow youths from the dole queues.

- New small firms may raise the degree of competition in the product market, bringing gains to consumers.

- Young entrepreneurs may be particularly responsive to new economic opportunities and trends.

- Greater self-employment among young people may go along with increased selfreliance and well-being.

- Economists have little evidence, however, on whether these hypothetical benefits exist in practice.

The beginning of the twenty-first century may mark a particularly appropriate time for young entrepreneurs. Some commentators argue that new opportunities abound - due to 
technological change, the fragmentation of markets, and increased deregulation across Europe.

In this paper we address questions of the following kind.

- Do young people want to be entrepreneurial, but are somehow prevented?

- Are those who manage to become self-employed actually better off, in terms of wellbeing (not just income), than those who do not?

- How, in a general sense, do young people perceive work?

\section{Background patterns in the data}

The most commonly studied class of entrepreneurs is those who are self-employed. Columns 1 and 2 of Table 1 provides background information on self-employment rates for those aged 25 and younger and those older than 25 years of age for a large number of EU countries. Here we define the self-employment rate across workers so it is the proportion of workers who are self-employed. The table shows that the self-employment figures vary greatly from one country to another. Figures are given in the table for the period 2001-2006 from a number of Eurobarometers. Some of the patterns in Table 1 are due to the differing importance of the agriculture sector, nation-by-nation. So selfemployment is particularly high in countries such as Turkey, Greece, Italy and Cyprus. For example, self-employment accounts for those over 25 accounts for forty-six per cent of workers in Greece, compared to less than nine per cent in Denmark. It is apparent that the self-employment rate of older workers is universally higher than it is for younger workers.

There is evidence from columns 3 and 4 of Table 1 that many more people would like to run their own businesses. The data come from 2000-2004 and are identical to questions reported in the 1997/8 International Social Survey Programme examined in Blanchflower, Oswald and Stutzer, (2001). It gives answers to one of the survey questions in a series of Flash Entrpreneurship Eurobarometers (see Blanchflower and Shadforth, 2007). Respondents are asked

Q. Suppose you were working and could choose between different kinds of jobs. Which of the following would you choose: being an employee or being self-employed?

Remarkably high numbers of individuals express a preference for self-employment. In most countries, large numbers of respondents said they would prefer being selfemployed. This is especially apparent for the young. As reported in Table 3 of Blanchflower et al (2001), in an equation estimating the probability that an individual would like to be self-employed, age enters negatively, controlling for a variety of characteristics. Table 1 appears to indicate - assuming questionnaire material can be viewed as reliable - that there is large latent demand for a kind of entrepreneurial behaviour - self employment. People find self-employment intrinsically attractive. 
Who, then, becomes self-employed? Table 2 provides information from regressions on self-employment (the dependent variable is a one/zero) for three countries using large micro-surveys at the level of the individual from the UK Labour Force Surveys of 20012007 (LFS); the Canadian Labour Force Surveys of 2001-2005 (CLFS) and the Merged Outgoing Rotation Group files of the Current Population Survey of 2001-2007 for the United States (MORG). There are nearly three million observations in total and nearly half a million young people between the ages of 16 and 25 in the data files. The procedure used is dprobit in STATA which fits maximum-likelihood probit models and is an alternative to probit. Rather than reporting the coefficients, dprobit reports the marginal effect, that is the change in the probability for an infinitesimal change in each independent, continuous variable and, by default, reports the discrete change in the probability for dummy variables. The table models how personal characteristics are related to the chance of running one's own business. The probability of being selfemployed for those aged over 25 , in all three countries, rises with age and is higher for men (Blanchflower, 2000, 2004, 2007). In the case of the US and Canada, the probability for older workers rises with education but declines with education in the UK (Blanchflower and Shadforth, 2007). In the whites have especially high rates, but in the UK rates are especially high among Asians from India, Pakistan and Bangladesh and among Chinese while in the US rates are high for whites. In the case of the young, aged 25 and under, the probability is higher for men in the US and the UK but lower in Canada. One half of all of the young self-employed in Canada are in childcare, jobs which are primarily held by young females. Probabilities decline with schooling in both Canada the UK for the young; the differences in the probabilities by different levels of schooling are less marked for the young in the US than for older workers.

Another important determinant of being self-employed that has been identified in the literature is having a self-employed parent. The probability of self-employment in the USA is substantially higher among the children of business owners than among the children of non-business owners (see Dunn and Holtz-Eakin 2000). These studies generally find that an individual who had a self-employed parent is roughly two to three times more likely to be self-employed than someone who did not have a self-employed parent. Broussard et al. (2003) found that the self-employed in the USA have between 2 and .4 more children compared to the non-self-employed. The authors argue that having more children can increase the likelihood that an inside family member will be a good match at running the business. One might also think that the existence of family businesses, which are particularly prevalent in construction and retailing, is a further way to overcome the existence of capital constraints. Analogously, Hout and Rosen (2000) found that the offspring of self-employed fathers are more likely than others to become self-employed and argued that the historically low rates of self-employment among African-Americans and Latinos may contribute to their low contemporary rates.

More recently Fairlie and Robb (2007) have demonstrated using data from the 1992 Characteristics of Business Owners (CBO) Survey found that more than half of all business owners had a self-employed family member prior to starting their business. Conditional on having a self-employed family member, less than 50 percent of small 
business owners worked in that family member's business suggesting that it is unlikely that intergenerational links in self-employment are largely due to the acquisition of general and specific business human capital and that instead similarities across family members in entrepreneurial preferences may explain part of the relationship. In contrast, estimates from regression models conditioning on business ownership indicated that having a self-employed family member plays only a minor role in determining small business outcomes, whereas the business human capital acquired from prior work experience in a family member's business appears to be very important for business success. Estimates from the CBO also indicated that only 1.6 percent of all small businesses are inherited suggesting that the role of business inheritances in determining intergenerational links in self-employment is limited at best.

Columns 1 and 2 of Table 3 reports the results of estimating the probability of being selfemployed as in Table 2 but now for Europe using three Flash Entrepreneurship Eurobarometers, 2002-2004. Three of the five years of data used in Table 1 include information on whether the respondent's parents were self-employed. having a mother or a father self-employed or both, raises the probability of an individual being selfemployed for both younger and older workers. Columns 3 and 4 now models the probability an individual when offered the choice of being an employee or self-employed chooses the latter. A father who is self-employed is especially important here.

Columns 1 and 2 of Table 4 are similar to the first two columns in that they once again estimate self-employment probabilities. The main difference now is the much larger sample size as data are drawn from a long time series of various Eurobarometers, covering the period 1973-2006. Column 1 is for those aged over 25 and column 2 for younger workers. In total there are nearly 400,000 observations on 30 countries, including the ten Accession countries from Eastern Europe plus Malta and Cyprus, along with candidate countries of Norway and Turkey. The probability of being self-employed rises with age and is higher for men. As was found for the UK, self-employment and education are negatively correlated.

There is some evidence in the literature that the self-employed are happier than employees (Blanchflower and Oswald, 2004; Blanchflower, 2004, 2007 and Blanchflower and Shadforth, 2007). Columns 3 and 4 of Table 4 suggests that both the younger and older self-employed groups are also especially happy. It is an ordered logit for individuals' reported life-satisfaction levels. The exact question asked is (with the scores inverted to ensure higher happiness has positive signs).

Q. Would you say you are very satisfied, fairly satisfied, not very satisfied, or not at all satisfied with the life you lead

1. not at all satisfied

2. not very satisfied

3. fairly satisfied

4. very satisfied 
The data come from the Eurobarometer Surveys of 1973 to 2006. Happiness is U-shaped in age (Blanchflower and Oswald, 2007) and married people are happier than singles and the unemployed have low happiness levels. Both young and old are the most unhappy if they lived in Bulgaria and the most happy living in Denmark. It is noticeable that for the two sub-samples the category 'self-employed' is statistically significant entering with a positive sign, showing that the self-employed have higher levels of satisfaction than the excluded category of employees with similar characteristics. Once more, therefore, the direct advantages to entrepreneurship seem clear. For whatever exact psychological reasons, self-employed young men and women are unusually satisfied with their lives.

In addition, self-employed young men and women are unusually satisfied with their jobs. The attitudes of young workers to various characteristics of their jobs are explored in Table 5. Data are taken from Eurobarometer \#54.2: Impact of New Technologies, Employment and Social Affairs, and Disabilities, January-February 2001. The sample is restricted to workers only. These data were previously examined in Blanchflower (2004). Responses are reported in relation to job satisfaction; earnings; the type of work and travel-to-work time. In each case the dependent variable is coded one through ten: the respondent was told that ' 1 ' meant not at all satisfied and '10' meant totally satisfied. For each of the four variables the self-employed are especially satisfied and this is true for both the younger and older age groups. The self-employed like their jobs and their earnings. Young workers are especially dissatisfied with their jobs in Greece and Portugal and with their earnings in Sweden.

\section{Entrepreneurship and Capital Constraints}

Economists have amassed considerable evidence that potential entrepreneurs are held back by lack of capital. Blanchflower and Oswald (1998), for example, found evidence that the receipt of an inheritance or gift seems to increase a typical individual's probability of being self-employed. This emerges from British data, the National Child Development Survey. NCDS traces from birth a cohort of children born in 1958. These individuals have been followed for the whole of their lives. Blanchflower and Oswald find a large association between self-employment and receiving money early on. The inheritance effect is found at age 23 and 33. It is especially large in the former and younger group. Blanchflower and Shadforth (2007) showed using a subsequent sweep of the NCDS that the inheritances, received before the age of 23 raised significantly the probability of being self-employed more than twenty years later, in 2004/5 at age 46 or 47.

Blanchflower, Levine and Zimmerman (2003) reported evidence from the 1993 and 1998 Survey of Small Business Finances from the United States. Although this tells us only about one country, the survey responses were intriguing. Interviewing a sample of minority-owned firms, the main explanation given by people to the survey team was that they had difficulty obtaining capital. Earlier work by Evans and Jovanovic (1989) and Holtz-Eakin, Joulfaian and Rosen (1994) drew similar conclusions using different methods on US data. Finally, Lindh and Ohlsson (1994) adopts the BlanchflowerOswald procedure and provides complementary evidence for Sweden. Blanchflower and Shadforth (2007) showed that rising house prices, which freed up capital constraints 
explain half of the recent increase in self-employment in the UK. This is consistent with Black et al (1996), for example, who found that a $10 \%$ rise in the value of unreleased net housing equity increases the number of new firm (VAT) registrations by some $5 \%$. Cowling and Mitchell (1997) estimate that in the UK a $10 \%$ rise in housing wealth increased the proportion of the workforce in self-employment by $3 \%$.

\section{Conclusions}

This paper documents some of the patterns in modern microeconomic data on young people's employment, attitudes and entrepreneurial behaviour. Among other sources, the paper uses the Eurobarometer Surveys; the Labour Force Surveys from Canada and the Current Population Survey in the United States.

The first conclusion is that self-employed individuals - a special but well-defined entrepreneurial group - report markedly greater well-being than equivalent employees. Their job satisfaction and life-satisfaction are all higher than workers of identical personal characteristics. While this finding does not tell us how to create more entrepreneurs in society, it does suggest that self-employment brings direct microeconomic benefits to people. It raises a puzzle, too. If self-employment does this, why are not more individuals running their own businesses?

The second conclusion is that individuals say they would like to be self-employed. There is, according to the survey data, a large pool of potentially entrepreneurial people. Across the West, many millions of employees would apparently prefer to be selfemployed. Questionnaire evidence, asking individuals about hypothetical outcomes, always needs to be treated with caution. Nevertheless, these answers are suggestive of an underlying interest in self-employment among large numbers of OECD citizens who are currently employees.

Third, we showed that another important determinant of being self-employed is having a self-employed parent. This appears to help young people to set up in business themselves. It is unclear whether this is done by inheriting the business, or working in the family firm or actually setting up a new business entirely.

How the paper's findings can be exploited by the designers of economic policy is more complicated to judge. Econometric and questionnaire research suggests that the main constraint on new entrepreneurs is a lack of start-up and liquid capital (as summarized in the paper's penultimate section). This does not mean that government cash ought to be handed out to those who wish to start a business. However, it indicates that plans to foster more entrepreneurship (if this is socially desirable) should begin by considering economists' evidence on the importance of capital constraints. 


\section{References}

Black, J., De Meza, D. and D. Jeffreys (1996), 'House prices, the supply of collateral, and the enterprise economy’, Economic Journal, 106, January, pp. 60-75.

Blanchflower, D.G. (2000), 'Self-employment in OECD countries', Labour Economics, 7, September, pp. 471-505.

Blanchflower, D.G. (2004), 'Self-Employment: more may not be better,' $\underline{\text { Swedish }}$ Economic Policy Review, 11(2), Fall, pp. 15-74

Blanchflower, D.G. (2007), 'Entrepreneurship in the United States', IZA Working Paper

Blanchflower, D.G., P. Levine and D. Zimmerman (2003), 'Discrimination in the small business credit market,' Review of Economics and Statistics, Vol. 85, Issue 4; 930-943, November.

Blanchflower D.G. and A.J. Oswald (1998), 'What makes an entrepreneur?', Journal of Labor Economics, January, 16(1) pp. 26-60.

Blanchflower D.G. and A.J. Oswald (2004), 'Wellbeing over time in Britain and the United States', Journal of Public Economics, 88(7-8), pp.1359-1386.

Blanchflower D.G. and A.J. Oswald (2007), 'Is wellbeing U-shaped over the life-cycle?', NBER WP\#12935,

Blanchflower, D. G., A.J. Oswald and A. Stutzer (2001), 'Latent entrepreneurship across nations,' European Economic Review, 45(4-6), May, pp. 680-691.

Blanchflower, D.G. and C. Shadforth (2007), 'Entrepreneurship in the UK', Foundations and Trends in Entrepreneurship, 3(4), pp. 257-364.

Broussard, N., R. Chami and G. Hess, (2003), '(Why) do self-employed parents have more children?', Working Paper, September.

Cowling M, and P. Mitchell (1997), 'The evolution of UK self-employment: a study of government policy and the role of the macroeconomy', Manchester School of Economic and Social Studies, 65(4), September, pp. 427-442.

Dunn, T. A. and D.J. Holtz-Eakin (2000), 'Financial capital, human capital, and the transition to self-employment: evidence from intergenerational links,' Journal of Labor Economics, 18 (2): 282-305.

Evans, D. and B. Jovanovic (1989), 'An estimated model of entrepreneurial choice under liquidity constraints', Journal of Political Economy, 97, pp. 808-827. 
Fairlie, R.W. and A. Robb (2007a), Families, human capital, and small business: evidence from the Characteristics of Business Owners Survey', forthcoming Industrial and Labor Relations Review.

Holtz-Eakin, D., Joulfaian, D., and H.S. Rosen (1994), 'Entrepreneurial decisions and liquidity constraints', Journal of Political Economy, 102, pp. 53-75.

Hout, M. and H.S. Rosen (2000), 'Self-employment, family background and race', Journal of Human Resources, 15(4), pp. 670-692.

Lindh T., and H. Ohlsson (1996). 'Self-employment and windfall gains: evidence from the Swedish lottery', Economic Journal, 106: (439), November, pp.1515-1526. 
Table 1. Self-employment rates among workers only, 2001-6 (\%)

\begin{tabular}{lcccc} 
& Over age 25 & sage 25 & Over age 25 & $\leq$ age 25 \\
& \multicolumn{2}{c}{$2001-2006$} & \multicolumn{2}{c}{ 2000-2004 } \\
Austria & Self-employment rate & Prefer self-employment \\
Belgium & 14.8 & 8.6 & 37.5 & 41.7 \\
Bulgaria & 15.5 & 10.6 & 34.6 & 48.3 \\
Croatia & 11.1 & 7.4 & - & - \\
Cyprus & 12.3 & 5.3 & - & - \\
Czech Republic & 32.7 & 29.8 & 62.5 & 68.4 \\
Denmark & 17.4 & 9.7 & 31.9 & 49.0 \\
Estonia & 8.5 & 3.9 & 36.4 & 59.0 \\
Finland & 10.1 & 4.8 & 36.5 & 71.4 \\
France & 13.5 & 12.4 & 28.2 & 27.0 \\
Germany & 11.7 & 7.9 & 41.9 & 53.1 \\
Greece & 11.7 & 6.2 & 42.1 & 50.1 \\
Hungary & 38.3 & 30.9 & 50.0 & 62.2 \\
Iceland & 10.0 & 6.0 & 45.0 & 67.7 \\
Ireland & $17.1^{\mathrm{a}}$ & $4.4^{\mathrm{a}}$ & 63.7 & 63.4 \\
Italy & 19.5 & 10.6 & 58.6 & 60.0 \\
Latvia & 29.5 & 23.6 & 54.1 & 73.8 \\
Lichtenstein & 9.6 & 4.9 & 39.0 & 63.4 \\
Lithuania & $15.6^{\mathrm{a}}$ & $5.7^{\mathrm{a}}$ & 52.3 & 57.9 \\
Luxembourg & 7.8 & 3.4 & 54.0 & 69.0 \\
Malta & 10.7 & 6.4 & 46.5 & 54.3 \\
Netherlands & 13.4 & 3.0 & 45.3 & 54.7 \\
Norway & 13.7 & 8.7 & 32.1 & 43.8 \\
Poland & 11.4 & $1.9^{\mathrm{a}}$ & 37.2 & 63.9 \\
Portugal & 22.3 & 10.0 & 53.8 & 53.7 \\
Romania & 21.1 & 13.0 & 65.6 & 77.7 \\
Slovakia & 18.9 & 15.3 & - & - \\
Slovenia & 12.4 & 6.2 & 33.1 & 39.7 \\
Spain & 12.8 & 6.9 & 33.3 & 42.2 \\
Sweden & 18.2 & 12.0 & 60.9 & 67.2 \\
Turkey & 11.5 & 6.9 & 35.0 & 45.2 \\
UK & 46.3 & 30.9 & - & - \\
USA & 10.8 & 6.8 & 44.1 & 49.0 \\
& $9.9^{\mathrm{b}}$ & $2.7^{\mathrm{b}}$ & 63.5 & 58.8
\end{tabular}

Source: columns 1 and 2 - Eurobarometers 2001-2006 ( $\mathrm{n}=110,878)$,. Columns 3 and 4 Flash Entrepreneurship Eurobarometers 2000-2004. "Suppose you could choose between different kinds of jobs, which one would you prefer being an employee or being selfemployed?" $(\mathrm{n}=33,913)$

Notes: ${ }^{\text {a }}$ means estimates obtained from Flash Entrepreneurship Eurobarometers ${ }^{\mathrm{b}}$ means estimates obtained from 2000, 2002, 2004 and 2006 General Social Surveys pooled $(\mathrm{n}=11494$ for age $>25$ and $\mathrm{n}=1410$ for age $\leq 25$. 
Table 2. Probability of being self-employed in the UK, Canada and the USA, 2001-2007 (dprobits)

\begin{tabular}{|c|c|c|c|c|c|c|}
\hline & $U K>25$ & $U K \leq 25$ & Canada $>24$ & Canada $\leq 24$ & $U S A>25$ & $U S A \leq 25$ \\
\hline & $2001-2007$ & $2001-2007$ & $2001-2005$ & $2001-2005$ & 2001-2006 & $2001-2006$ \\
\hline Age* & $.0033(102.62)$ & $.0060(36.83)$ & $.1545(58.49)$ & $-.0026(1.88)$ & $.0037(129.11)$ & $.0037(22.86)$ \\
\hline Male & .0984 (142.97) & $.0350(40.90)$ & $.0777(77.35)$ & $-.0084(7.78)$ & $.0607(91.85)$ & $.0153(20.48)$ \\
\hline Mixed & $-.0070(1.36)$ & $-.0049(1.39)$ & & & & \\
\hline Asian & $.0399(19.44)$ & $-.0038(2.08)$ & & & $-.0230(13.58)$ & $-.0074(3.76)$ \\
\hline Black & $-.0530(20.60)$ & $-.0157(5.51)$ & & & $-.0658(54.42)$ & $-.0082(6.25)$ \\
\hline Chinese & $.0646(10.37)$ & $-.0113(2.02)$ & & & & \\
\hline Other race & $.0015(0.43)$ & $-.0151(4.52)$ & & & $-.0443(34.93)$ & $-.0097(8.72)$ \\
\hline Native American & & & & & $-.0463(14.83)$ & $-.0007(0.21)$ \\
\hline Hispanics & & & & & $-.0540(18.56)$ & $-.0135(5.88)$ \\
\hline School 2 & $-.0195(15.64)$ & $.0141(6.15)$ & $-.0424(19.45)$ & .0105 (0.94) & $.0772(21.74)$ & $.0000(0.00)$ \\
\hline School 3 & $.0307(30.13)$ & $.0193(13.56)$ & $-.0441(22.09)$ & $.0188(1.70)$ & $-.0543(24.54)$ & $-.0199(2.73)$ \\
\hline School 4 & $-.0064(6.07)$ & $.0160(10.80)$ & $-.0327(13.24)$ & $.0018(0.18)$ & $-.0279(12.19)$ & $-.0214(2.68)$ \\
\hline School 5 & $-.0150(13.03)$ & $.0261(12.71)$ & $-.0395(19.12)$ & $.0108(1.03)$ & $-.0478(19.74)$ & $-.0166(2.01)$ \\
\hline School 6 & $.0076(6.08)$ & $.0529(19.01)$ & $-.0301(13.39)$ & $.0561(4.72)$ & $-.0368(15.22)$ & $-.0133(1.46)$ \\
\hline School 7 & $.0214(5.11)$ & $.0362(5.79)$ & $-.0214(7.55)$ & $.1669(8.07)$ & $-.0281(12.24)$ & $-.0224(2.25)$ \\
\hline High school graduate & & & & & $-.0376(16.56)$ & $-.0178(1.71)$ \\
\hline $12^{\mathrm{th}}$ grade No diploma & & & & & $-.0421(11.64)$ & $-.0141(1.58)$ \\
\hline $11^{\text {th }}$ grade & & & & & $-.0331(10.93)$ & $-.0125(1.28)$ \\
\hline $10^{\text {th }}$ grade & & & & & $-.0279(8.84)$ & $-.0063(0.58)$ \\
\hline $9^{\text {th }}$ grade & & & & & $-.0315(9.13)$ & $-.0045(0.41)$ \\
\hline $7^{\text {th }} / 8^{\text {th }}$ grade & & & & & $-.0139(4.02)$ & $.0005(0.04)$ \\
\hline $5^{\text {th }} / 6^{\text {th }}$ grade & & & & & $-.0541(15.44)$ & $-.0155(1.78)$ \\
\hline $1-4^{\text {th }}$ grade & & & & & $-.0660(14.29)$ & $-.0158(1.69)$ \\
\hline$<1^{\text {st }}$ grade & & & & & $-.0628(8.76)$ & $-.0081(0.64)$ \\
\hline Year dummies & 5 & 5 & 4 & 4 & 5 & 5 \\
\hline Area dummies & 19 & 19 & 9 & 9 & 51 & 51 \\
\hline Pseudo $\mathrm{R}^{2}$ & .0531 & .0766 & .0595 & .0529 & .0540 & .0322 \\
\hline $\mathrm{N}$ & $1,041,559$ & 171,194 & 567,691 & 129,690 & $1,026,349$ & 185,067 \\
\hline
\end{tabular}


Notes: In the case of Canada the age variable is for 50-54 and 20-24 half of the $<=24$ year old self-employed are in childcare. For Canada education categories are excluded=university graduate degree; school2=university bachelor's degree; school3=post-secondary certificate or diploma; school4=some post-secondary; school5=grade 11to 13, graduate; school6=some secondary; school7=0 to 8 years schooling.

For the USA excluded category is PhD, school2=MBA; school3=MA; school4=BA: school5=associate degree academic; school6= associate degree vocational; school $7=$ some college no degree

For the UK excluded category is Degree or equivalent; school2= Higher Education; school3=GCE A Level or equivalent; school4=GCSE grades A*-C or equivalent; school5=Other qualification; school6=No qualification; school 7=Don't know T-statistics in parentheses.

Sources: UK- Labour Force Surveys, March 2001-June 2007; USA - Merged Outgoing Rotation Group files of the Current Population Survey, 2001-2006 and Canada - Labour Force Surveys, 2001-2005.

Mean self employment rates

\begin{tabular}{|c|c|c|c|c|}
\hline UK $\leq 25$ years & $3.5 \%$ & USA $\leq 25$ years & $2.6 \%$ & Canada $\leq 25$ years \\
\hline $\mathrm{UK}>25$ years & $14.1 \%$ & USA $>25$ years & $13.4 \%$ & Canada $>25$ years \\
\hline
\end{tabular}


Table 3. Probability of being self-employed and choosing self-employment, 2002-2004

\begin{tabular}{|c|c|c|c|c|}
\hline & \multicolumn{2}{|c|}{ Self-employment } & \multicolumn{2}{|c|}{ Choosing self-employment } \\
\hline & Over age 25 & $\leq$ age 25 & Over age 25 & $\leq$ age 25 \\
\hline Mother self-emp & $.0343(6.37)$ & $.0209(3.68)$ & $.0344(3.75)$ & $.0365(1.78)$ \\
\hline Father self-emp & $.0711(16.31)$ & $.0244(5.42)$ & $.0889(12.64)$ & $.0613(4.04)$ \\
\hline Age & $.0176(19.44)$ & $-.0079(5.48)$ & $-.0049(3.88)$ & $.0142(1.89)$ \\
\hline Male & $.0037(1.14)$ & $.0029(0.92)$ & $-.0017(0.32)$ & $-.0087(0.72)$ \\
\hline $\mathrm{Age}^{2}$ & $-.0001(21.09)$ & $.0003(7.75)$ & $.0000(3.42)$ & $-.0005(2.44)$ \\
\hline Austria & $-.0054(0.49)$ & $-.0210(2.90)$ & $-.0970(5.38)$ & $-.0645(1.41)$ \\
\hline Belgium & $-.0194(1.97$ & $-.0155(1.75)$ & $-.1175(7.16)$ & $-.0541(1.30)$ \\
\hline Cyprus & $.0518(2.83$ & $-.0200(3.17)$ & $.1592(5.41)$ & $.1655(2.93)$ \\
\hline Czech Republic & $.0637(4.36$ & $-.0043(0.60)$ & $-.1182(5.33)$ & $-.0050(0.10)$ \\
\hline Denmark & $-.0526(5.30$ & $-.0174(2.91)$ & $-.1164(6.48)$ & $.0593(1.21)$ \\
\hline Ireland & $.0529(4.34)$ & $-.0237(3.74)$ & $.1259(6.72)$ & $.0730(1.91)$ \\
\hline Estonia & $-.0151(0.86)$ & $-.0205(3.44)$ & $-.0698(2.39)$ & $.2067(3.33)$ \\
\hline Finland & $.0002(0.02)$ & $-.0114(1.63)$ & $-.2043(11.26)$ & $-.2395(5.56)$ \\
\hline France & $-.0613(7.10)$ & $.0586(3.98)$ & $-.0475(3.06)$ & $.0105(0.28)$ \\
\hline Germany & $-.0118(1.26)$ & $-.0178(2.42)$ & $-.0342(2.20)$ & $.0028(0.07)$ \\
\hline Greece & $.1006(8.40)$ & $-.0133(1.73)$ & $.0208(1.23)$ & $.0795(2.15)$ \\
\hline Hungary & $.0265(1.91)$ & $-.0190(3.05)$ & $.0155(0.72)$ & $.1713(3.35)$ \\
\hline Iceland & $.0396(3.31)$ & $-.0219(3.12)$ & $.1174(6.02)$ & $.0730(1.82)$ \\
\hline Italy & $.0073(0.75)$ & $-.0182(2.43)$ & $.0764(4.88)$ & $.1992(5.47)$ \\
\hline Latvia & $-.0568(3.31)$ & $.0081(0.59)$ & $-.0463(1.62)$ & $.1295(2.42)$ \\
\hline Lithuania & $.0017(0.16)$ & $-.0136(1.53)$ & $.0406(2.19)$ & $.0745(1.75)$ \\
\hline Lichtenstein & $-.0384(2.19)$ & $-.0076(0.51)$ & $.0989(3.41)$ & $.1827(3.26)$ \\
\hline Luxembourg & .1507 (11.27) & $-.0150(1.52)$ & $-.0236(1.31)$ & $-.0029(0.07)$ \\
\hline Malta & $-.0495(2.94)$ & $-.0161(1.43)$ & $.0046(0.16)$ & $-.0130(0.21)$ \\
\hline Netherlands & $-.0133(1.38)$ & $-.0121(0.95)$ & $-.1553(9.68)$ & $-.0858(1.95)$ \\
\hline Norway & $-.0024(0.23)$ & $-.0200(1.70)$ & $-.1240(6.83)$ & $.0527(1.10)$ \\
\hline Poland & $.0154(1.12)$ & $-.0124(1.50)$ & $.0758(3.40)$ & $.0185(0.43)$ \\
\hline Portugal & $.0032(0.31)$ & $.0010(0.09)$ & $.2047(11.94)$ & $.2669(7.51)$ \\
\hline Slovakia & $.0534(2.78)$ & $-.0156(1.40)$ & $-.1149(3.85)$ & $-.0903(1.54)$ \\
\hline Slovenia & $-.0568(3.36)$ & $-.0079(0.97)$ & $-.1188(4.09)$ & $-.0664(1.18)$ \\
\hline Spain & $-.0087(0.90)$ & $-.0151(2.19)$ & $.1364(8.39)$ & $.1408(4.04)$ \\
\hline Sweden & $-.0230(2.15)$ & $-.0190(2.36)$ & $-.1251(6.95)$ & $-.0604(1.29)$ \\
\hline USA & $.0274(2.63)$ & $.0085(0.98)$ & $.1834(11.31)$ & $.1084(3.04)$ \\
\hline ALS 16-19 & $.0145(1.25)$ & .0092 (1.07) & $-.0452(2.54)$ & $-.0470(1.54)$ \\
\hline ALS 20+ & $.0274(2.48)$ & $.0038(0.67)$ & $-.0411(2.37)$ & $-.0355(1.42)$ \\
\hline Still studying & $.0502(4.35)$ & $-.0092(1.52)$ & $-.0174(1.00)$ & $-.0395(1.33)$ \\
\hline Pseudo $\mathrm{R}^{2}$ & .0755 & .1433 & .0456 & .0426 \\
\hline $\mathrm{N}$ & 35,451 & 7,133 & 33,312 & 6,886 \\
\hline
\end{tabular}

Source: Flash Entrepreneurship Eurobarometers, 2002-2004. T-statistics in parentheses Notes: equations also include two year dummies. UK is excluded. 
Table 4. Probability of being self-employed and life satisfaction, Europe - 1973-2006

\begin{tabular}{|c|c|c|c|c|}
\hline & Self-employr & nt probability & Life satis & faction \\
\hline & Over age 25 & $\leq$ age 25 & Over age 25 & $\leq$ age 25 \\
\hline Age & $.0051(78.24)$ & $.0041(9.73)$ & $-.0385(32.78)$ & .0487 (9.57) \\
\hline $\mathrm{Age}^{2}$ & & & $.0004(36.57)$ & $-.0017(11.73)$ \\
\hline Male & $.0575(40.04)$ & $.0397(18.15)$ & $-.1025(17.96)$ & $-.0800(7.87)$ \\
\hline Time trend & & & $.0013(4.17)$ & $.0057(8.70)$ \\
\hline Self-employed & & & $.0332(3.81)$ & $.0833(3.23)$ \\
\hline Home & & & $-.0374(4.52)$ & $-.1420(6.23)$ \\
\hline Student & & & $.0117(0.27)$ & $.1769(6.45)$ \\
\hline Retired & & & $-.0966(10.77)$ & $-.3910(10.27)$ \\
\hline Unemployed & & & $-.9911(83.73)$ & $-.9022(47.85)$ \\
\hline ALS 16-19 & $-.0278(15.39)$ & $-.0121(4.04)$ & $.2396(37.84)$ & $.1637(9.85)$ \\
\hline ALS 20+ & $-.0241(12.43)$ & $-.0026(0.70)$ & $.4823(64.78)$ & 18.17) \\
\hline Still studying & $-.0427(3.52)$ & $-.0232(2.80)$ & $.2153(5.16)$ & $.3004(10.40)$ \\
\hline Married & & & $.3956(47.45)$ & $.2260(14.53)$ \\
\hline Living together & & & $.1876(13.60)$ & $.1477(7.94)$ \\
\hline Divorced & & & $-.3494(25.48)$ & $-.7441(14.63)$ \\
\hline Separated & & & $-.4896(22.23)$ & $-.5760(8.28)$ \\
\hline Widowed & & & $-.1866(15.50)$ & $-.3171(5.53)$ \\
\hline Austria & $.0867(15.38)$ & $.0383(4.32)$ & $-.3099(16.97)$ & -.159 \\
\hline Belgium & $.0965(24.890$ & .0435 (7.29) & $-.2589(21.19)$ & $(2.30)$ \\
\hline Bulgaria & $.0344(2.73)$ & $.0812(2.72)$ & $-3.0543(90.78)$ & -2.1829 \\
\hline Croatia & $.0630(4.77)$ & $.0472(1.54)$ & $-1.2832(36.10)$ & $-.3371(4.09)$ \\
\hline Cyprus & $.2917(25.09)$ & $.3976(13.16)$ & $-.2958(7.92)$ & $.1003(1.21)$ \\
\hline Czech Re & $.1251(11.72)$ & $.1325(4.36)$ & $-.9971(30.81)$ & $-.4984(5.89)$ \\
\hline Denmark & $-.0094(2.70)$ & $-.0428(7.67)$ & $1.0734(85.34)$ & $1.1841(45.79)$ \\
\hline Estonia & $.0102(0.87)$ & $.0383(1.23)$ & $-1.5259(45.16)$ & $(11.20)$ \\
\hline Finland & $.0526(8.91)$ & $.0642(6.25)$ & $-.2058(11.27)$ & $.0033(0.10)$ \\
\hline France & $.0612(16.46)$ & $.0038(0.71)$ & $-1.0225(83.55)$ & -.769 \\
\hline Germany & $.0083(2.55)$ & $-.0168(3.44)$ & $-.6872(63.04)$ & -.6765 \\
\hline Greece & $.3664(81.14)$ & $.2722(32.44)$ & $-1.6083(121.29)$ & $-1.1353(44.57)$ \\
\hline Hungary & $.0149(1.13)$ & $.0562(1.76)$ & $-1.9181(58.49)$ & $-1.2570(13.13)$ \\
\hline Ireland & $.1980(47.28)$ & $.0794(13.83)$ & $.0840(6.65)$ & $3.17)$ \\
\hline Italy & $.2013(50.33)$ & $.1839(25.07)$ & $-1.1271(92.03)$ & $-.8733(37.41)$ \\
\hline Latvia & $.0083(0.72)$ & $.0391(1.44)$ & $-1.8559(55.77)$ & $-1.0335(13.62)$ \\
\hline Lithuania & $-.0195(1.52)$ & $.0111(0.33)$ & $-1.9429(57.38)$ & $-.6400(7.79)$ \\
\hline Luxembourg & $.0245(4.92)$ & $-.0053(0.72)$ & $.3288(20.11)$ & $.2194(6.90)$ \\
\hline Malta & $.0741(3.64)$ & $-.0019(0.05)$ & $-.3693(7.53)$ & $-.1810(1.43)$ \\
\hline Netherlands & $.0234(6.16)$ & $.0002(0.03)$ & $.4361(35.99)$ & $.5910(23.74)$ \\
\hline Norway & $.0127(1.67)$ & $.0287(1.92)$ & $.4358(15.34)$ & $.6090(11.32)$ \\
\hline Poland & $.2116(15.64)$ & .1336 (3.99) & $-1.3646(38.71)$ & $-.4069(5.42)$ \\
\hline Portugal & $.1678(36.73)$ & .0643 (9.79) & $-1.5238(109.95)$ & $-1.0356(40.25)$ \\
\hline Romania & $.1453(11.64)$ & $.2339(7.49)$ & $-2.4206(70.68)$ & $-1.6739(20.67)$ \\
\hline Slovakia & $.0504(4.84)$ & $.0828(2.76)$ & $-1.7167(53.90)$ & $-1.2235(13.55)$ \\
\hline
\end{tabular}




\begin{tabular}{lcc|cc} 
Slovenia & $.0686(5.64)$ & $.0728(2.28)$ & $-.3816(10.92)$ & $-.0322(0.42)$ \\
Spain & $.1568(33.14)$ & $.0739(10.52)$ & $-.6530(46.20)$ & $-.3713(14.53)$ \\
Sweden & $-.0014(0.26)$ & $-.0040(0.42)$ & $.3476(19.15)$ & $.3740(10.08)$ \\
Turkey & $.4504(29.35)$ & $.3924(14.10)$ & $-.8374(19.54)$ & $-.4114(5.89)$ \\
cut1 & & & -4.2661 & -3.3319 \\
cut2 & & & -2.4728 & -1.5287 \\
cut3 & 31 & 31 & .3414 & 1.3615 \\
Year dummies & & & 0 & 0 \\
& .0845 & .0910 & .0873 & .0675 \\
Pseudo R & & & 620,765 & 162,786 \\
$\mathrm{~N}$ & 328,402 & 66,875 & &
\end{tabular}

Source: Trend Eurobarometers 1975-2002 and various subsequent Eurobarometers.

Excluded categories ALS $<16$; UK

Notes: columns 1 and 2 are dprobits and columns 3 and 4 ordered logits. T-statistics in parentheses 
Table 5. Satisfaction with work - Europe 2001

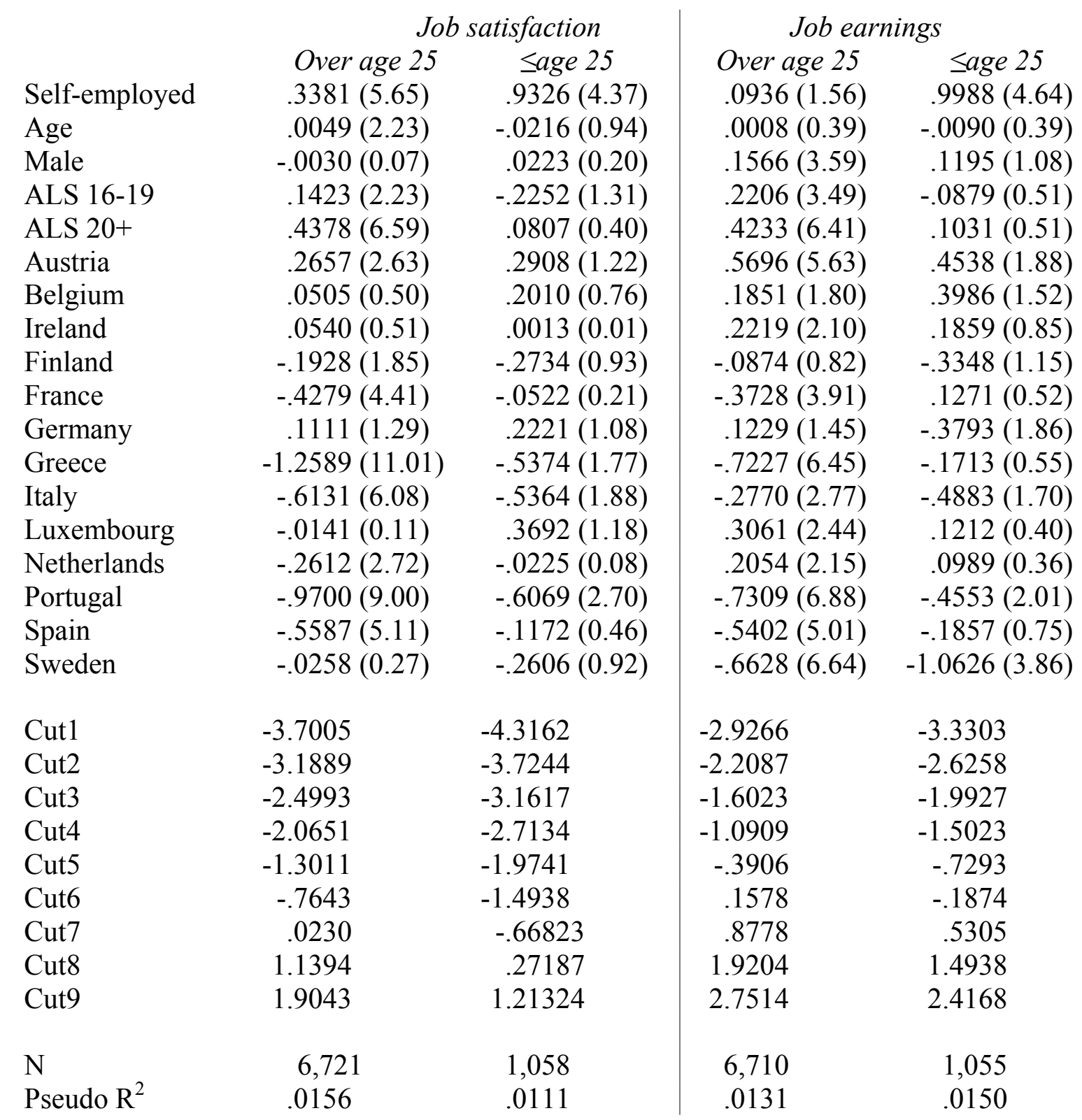

Source: Eurobarometer 54.2: Impact of New Technologies, Employment and Social Affairs, and Disabilities, January-February 2001. Excluded category UK.

a) On the whole, how satisfied are you with your current job or business? Please use the following scale from 1 to 10 , where ' 1 ' means that you are not at all satisfied and '10' means that you are totally satisfied. You can use the numbers in between. (SHOW CARD WITH SCALE). b) And how satisfied are you with your current job or business in terms of earnings. c) And in terms of the type of work you do? (SHOW SAME CARD). d) And in terms of the time it takes to travel to work? (SHOW SAME CARD) T-statistics in parentheses 